\title{
From the Indian Ocean to the Pacific: Affranchis and Petits- Blancs in New Caledonia
}

\author{
Karin Speedy, Macquarie University
}

The sugar crisis of 1860 in the Indian Ocean island of Réunion motivated the migration of thousands of Réunionnais to New Caledonia in the Pacific. Along with sugar planters, wealthy enough to transport their production equipment as well as their indentured workers, significant groups of both skilled and unskilled labourers made their way from Réunion to the Pacific colony in the second half of the nineteenth century. In previous publications, I have focused my attention on the sugar industry and the immigration of the rich planters and their coolies. ${ }^{1}$ While I have drawn attention to the heterogeneity of the sugar workers and have signalled the arrival and numeric importance of tradespeople, manual and low skilled workers from Réunion, I have not yet described these immigrants in detail. This is because this group has been largely ignored by history and details surrounding their circumstances are scant. In this paper, I discuss the background and origins of these people and highlight some of the fascinating stories to emerge from this migration to New Caledonia and beyond.

From the earliest days of French settlement, immigrants from the Indian Ocean island of Réunion settled in New Caledonia. These 'pioneers' were generally involved in agricultural activities, laying the foundations for the sugar and coffee industries that would attract many of their compatriots in the coming years. In 1863, in a quest to populate the nascent colony, New Caledonian Governor Guillain made a special appeal

\footnotetext{
${ }^{1}$ For details see Speedy (2007a, 2007b, 2008, 2009).

PORTAL Journal of Multidisciplinary International Studies, vol. 9, no. 1, January 2012. Indian Ocean Traffic Special Issue, guest edited by Lola Sharon Davidson and Stephen Muecke. ISSN: 1449-2490; http://epress.lib.uts.edu.au/ojs/index.php/portal PORTAL is published under the auspices of UTSePress, Sydney, Australia.
} 
to the 'Créoles de la Réunion,' 2 who were enduring great hardship following the sugar crisis on their island. Once the Pacific lands were met with approval by the head of Réunion's exploratory expedition, Louis de Nas de Tourris, Réunionnais began arriving en masse. ${ }^{3}$

In addition to the documented arrivals of wealthy sugar planters, often accompanied by their contingent of engagés (indentured or contract workers), the ships' lists published in the Moniteur de la Nouvelle-Calédonie and the registers of the État Civil of nineteenth century New Caledonia bear witness to the presence in the colony of a substantial group of migrants who seem to belong neither to the wealthy class of Grands Blancs nor to the 'coolie' population. ${ }^{4}$ Others, while perhaps entering the colony as contract labourers for the sugar planters, were certainly not 'Malabars' ${ }^{5}$ and were quickly absorbed into New Caledonia's free population once their contracts terminated. These men and women lived on and around the sugar-producing centres of southern New Caledonia or in Nouméa. Once the sugar industry collapsed from the late 1870s, there was a drift towards the capital. Other Réunionnais settled further north, around Moindou, La Foa, Canala, Sarraméa, Nakéty, Houaïlou and Ponérihouen (Speedy 2007a: 95-103).

\section{Characteristics of the Immigrants}

Aside from their occupations, which tended to be either in agriculture, trades or lowskilled labour, this group shared other characteristics that indicate that they were probably drawn from the 'most ill-treated" ${ }^{3}$ of Réunion's population who were spiralling into moral decline and poverty (see Delignon 1898: 49). In other words, they were either from the Affranchi (freed slave) population or the increasingly impoverished Petits-Blancs. Some of the characteristics include their filiation—at times this was

\footnotetext{
${ }^{2}$ In Réunion, the term Creole was and still is applied to anyone born on the island of White, Black or mixed heritage but was not extended to later groups of immigrants such as the Indian engagés (Malabars), Muslim Indians or Chinese (see Chaudenson 1992: 9).

${ }^{3}$ For an account of Governor Guillain’s appeal to the Creoles of Réunion and Nas de Tourris's report on the suitability of New Caledonia's lands for colonisation, see Le Moniteur de la Nouvelle-Calédonie, 6 November 1864, no. 267.

${ }^{4}$ I consulted registers of the État Civil (registers of births, deaths and marriages) of Nouméa (1863-1899), Dumbéa (1875-1898), Mont-d’Or (1879-1898) and Païta (1870-1899) at the Centre des Archives d'OutreMer in Aix-en-Provence in 2005 and 2008. Unfortunately, due to their state of disrepair, I was not able to consult many of the registers for Nouméa, including 1860-1862, 1875, 1878-1885, 1888-1890, 1892 , 1893, 1895 and 1896. Future research may well uncover more Réunionnais living in New Caledonia and shed more light on their backgrounds.

5 'Malabar' is a term used in Réunion and New Caledonia to refer to non-Muslim Indians.

${ }^{6}$ This and all other translations are my own.
} 
‘unknown' and a number were listed as enfants naturels (illegitimate children). For others, the fact that their father had only one name that in turn became their family name meant that they were undoubtedly born to slaves or ex-slaves. Elisa Ozénor, Dame Ulice, for instance, who died in 1873 at the age of thirty-one, was the legitimate child of Ozénor and Dalle. ${ }^{7}$ While many of this group married, often among themselves, de facto relationships were also fairly common. The children born to unmarried couples were generally recognised by their fathers although a few, such as Aline Antoine's daughters, took their unmarried mother's surname. ${ }^{8}$ In addition, the court records published in the Moniteur de la Nouvelle-Calédonie, demonstrate that some members of this group operated outside of the law. A few examples of the crimes committed by the Réunionnais include theft, fraud, vagrancy, bootlegging, public drunkenness and public indecency. ${ }^{9}$

In a few cases, the behaviour and indigence of certain migrants was such that it led ultimately to their repatriation. Commenting on the unsuitability of some of the Réunionnais and other free immigrants, Julien Bernier, prominent journalist in New Caledonia and Réunionnais himself, wrote: 'In Réunion, as in France, destitute and marginalised town-dwellers were recruited far too easily. All these people did was come here and give us the spectacle of their idleness before being repatriated as paupers' ( $L e$ Néo-Calédonien, 28 May 1884). However, many others were able to make new lives for themselves in the Pacific. Lucien Delignon notes that the Réunionnais workers were 'generally successful, when they conducted themselves honestly, thanks to their thrifty and sober ways’ (1898: 49). And, in another article on free immigration, Julien Bernier lauds the ‘Creole immigration' of the 1860s and 1870s, pointing out that Réunionnais could be found 'everywhere in commerce, industry and even in the liberal professions' and that their aptitudes in agriculture were particularly appreciated in New Caledonia (Le Néo-Calédonien, 5 May 1884).

While Bernier criticizes the recruitment of impoverished urbanites, many of whom were most likely Affranchis, he promotes a group of Réunionnais who, in his view, were more apt to immigrate, namely the Petits-Blancs of the cirques:

\footnotetext{
${ }^{7}$ DPPC EC NCL/NOUMEA/9 (1873).

${ }^{8}$ DPPC EC NCL/DUMBEA/1 (1875-1886), DPPC EC NCL/NOUMEA/8 (1872).

${ }^{9}$ See, for instance, Le Moniteur de la Nouvelle-Calédonie, 4 September 1872, no. 676 and Le Moniteur de la Nouvelle-Calédonie, 13 November 1872, no. 686.
} 
In Réunion, living up on the inland cirques, there are large numbers of people who are struggling to survive by working the land. They live almost entirely on corn and consume only what they are able to grow themselves. For these people, a twenty-four-hectare property, including four hectares of prime land, in New Caledonia's salubrious climate would represent a true fortune. (Le NéoCalédonien, 28 May 1884)

The Petits-Blancs too seem the target of the article published in Réunion's local newspaper on emigration to New Caledonia in 1868. At a time when Réunionnais administrators were facing the problems of overpopulation, underemployment and increasing poverty among the then practically landless poor whites, A. Marchand's letter calling for white immigration must have had some impact (Le Moniteur de la Réunion, 10 June 1868). In 1870, the New Caledonian governor, Gaultier de la Richerie, made an appeal for further Creole immigration to the Pacific, urging Réunionnais already living in New Caledonia to tell their former compatriots that they would find 'everything here that they do not have there, that is land where they can devote themselves, in freedom and safety, to their agricultural, industrial or commercial ventures’ (Le Moniteur de la Nouvelle-Calédonie, 28 August 1870). Many people heeded these calls and, between 1867 and 1875, a second wave of Creole immigrants disembarked in New Caledonia, ready to start their new lives (Speedy 2007a: 83-107). Again, these migrants appeared to be from all walks of life and social backgrounds; they were rural and urban, indentured and free, black, white and, most predominantly, métis.

\section{Social classification}

In an interesting parallel between the old Indian Ocean colony of Réunion and the newest French colony in the Pacific, people were classified, not by the colour of their skin, but by their social status. The complex nature of this classification in Réunion is discussed below, where the essential distinction was made between free and servile (slave and later engagé) populations. In New Caledonia, the division was made between free, convict and indigenous populations. While the obvious ethnic difference in the Réunionnais appearance did not go entirely unnoticed in New Caledonia - Monsignor Vitte referred to them in 1874 as the 'Bourbon mulattoes ${ }^{10}$ and Christiane Terrier, commenting on the phenomenon of the 'melting-pot' in New Caledonian free society, notes that the Bourbonnais were reputed to be 'nonchalant' but more likely just a bit too 'coloured ${ }^{11}$ — they were all classified as belonging to the local 'white' (free)

\footnotetext{
${ }^{10}$ Quoted by Ehrhart (1994: 21). Note that the Réunionnais were often called Bourbonnais in nineteenth century New Caledonia in reference to the island's former name (Bourbon).

${ }^{11}$ See Terrier (2000: 134) and Terrier-Douyère (1998: 378) for details.
} 
population.

However, as evidenced by surviving photos of some Réunionnais immigrants such as Jolimont Kabar (Angleviel \& Milin 2004: 14), Charles Mitride (Delathière 2004: 91) and the photos of some of the members of the Montrose and Florian families in this article, many of the Réunionnais were not 'biologically’ white. If the New Caledonian tradition of the 'non-dit' (or the unspoken) means that we do not have much evidence of overt racism against the Réunionnais, many of whom were black or metis, Christiane Terrier's comment about them being 'too coloured' rather than 'nonchalant' indicates that, at least in the beginning, they perhaps felt somewhat excluded from New Caledonian society and were inclined to group together. The first generation certainly tended to intermarry, with 63 percent of the unions recorded in the registers of the État Civil of southern New Caledonia involving two Réunion Islanders (Speedy 2007a: 104).

That many of the Réunionnais who arrived in New Caledonia were of mixed ethnic heritage is not surprising given the particular socio-demographic history of Réunion. Métissage is 'very ancient, deep and widespread' (Nicole 1996: 19) and ethnically mixed people were found among the ruling and servile classes as well as among the Petits-Blancs and Affranchis. In order to gain a greater understanding of the identities of the Creole immigrants, it is therefore important to highlight something of the population and social history of Réunion.

\section{Social status and ethnicity in Réunion}

Métissage has in fact been a feature of the socio-demographic history of Réunion since the first Europeans arrived with their Malagasy and Indo-Portuguese partners and wives in the late 1660s. ${ }^{12}$ The large majority of the first generation of Creoles, or locally-born inhabitants, were métis and ethnic mixing continued as these children in turn chose métis, Malagasy or Indian spouses from the limited pool of available partners on the island. An acute shortage of women saw the importation from India of twelve IndoPortuguese women in 1678, all of whom were immediately married off to colonists. A number of pirates, some Frenchmen and a few other men of different nationalities subsequently settled on the island, but no more women arrived until 1718 . The population grew largely thanks to the fertility of the women who were married, often to

\footnotetext{
${ }^{12}$ Information in this section is based on Barassin (1978), Bourquin (2005), Prudhomme (1984), and Fuma (1998).
} 
much older men, as soon as they reached puberty. They usually outlived several husbands and lovers and bore large numbers of legitimate (and some illegitimate) children.

Despite their mixed origins, the Creoles were classified as belonging to the white or European population by virtue of their French family name. The Indian and Malagasy partners of the French colonists were also included in the group. As slavery began to take off in the eighteenth century, the main distinction between social groups became that of slave and free. In his 1710 Mémoire pour servir à la connoissance particulière de chacun des habitans de l'isle de Bourbon, Antoine Boucher gives several examples of Malagasy or Indian wives inheriting their husband's slaves. Perhaps the most striking case is that of the 'Negress of Madagascar,' Anne Caze, widow of Gilles Launay, who became mistress of fourteen slaves upon his death. Given that these slaves included her sister Marguerite, two of her brothers-in-law and her nieces and nephews, it was somewhat unsurprising that she was said to treat her slaves 'like her own children' (Barassin 1978: 64).

The move from a 'homestead society' to a 'plantation society' (Chaudenson 1992: 2003) with the growth of coffee production from around 1725 and later, towards the end of the century, sugar, and the subsequent arrival of large numbers of slaves from Madagascar, India, West Africa and Mozambique, meant that greater social distance was created between the large land-holders on the one hand and the slaves on the other. At the same time, the social distance became more acute between the landowners who were able to capitalise on the shift towards a monoculture and those who, due to population growth and heritage laws that saw their properties reduced to tiny, unproductive lots, were not. From this point on, the Grands Blancs would dominate Réunion's economic and social development and the Petits-Blancs would become increasingly impoverished and marginalised, eventually retreating to the Hauts. ${ }^{13}$ According to historian Daniel Vaxelaire, Réunionnais society differed from other colonial societies due to the existence of an intermediary class made up of Petits-Blancs and free people of colour. He writes:

\footnotetext{
${ }^{13}$ The Hauts or the cirques in the centre of the island became the place of refuge for many Petits-Blancs who had lost their lands to the large-scale coffee and then sugar growers. Maroon slaves had also retreated to the mountainous, volcanic Hauts and, after the abolition of slavery in 1848, some freed slaves also drifted to this area. The soils and conditions in the Hauts being far inferior to those along the coastline, many Petits-Blancs and Affranchis faced starvation as they tried to survive off the land.
} 


\begin{abstract}
Well before the abolition of slavery, Bourbon society differed greatly from the 'model' colonial society. At the top of the social pyramid, not all landowners were white. At the bottom, not all slaves were African. A rapidly growing middle or intermediary class was made up of two groups of differing origins but who were drawing ever closer: the 'free people of colour,' freed slaves or their descendants (amongst whom there was a large number of métis) and the 'poor whites,' a group that was also more and more ethnically mixed. (quoted in Bollée 2007: 109)
\end{abstract}

Moreover, while a law did exist from 1674 prohibiting intermarriage between black and white, it was somewhat irrelevant and most often ignored in a society built on métissage. Historian Sudel Fuma’s (1998) research on Réunion’s État Civil and documents concerning the emancipation of slaves before the general emancipation of 1848 demonstrates that this métissage continued throughout the eighteenth and nineteenth centuries. Aside from the common unions between masters and slave women, which led in some cases to emancipation, and mixing between the Petits-Blancs and free people of colour, Fuma (1998) outlines a family history that underlines the fluidity between black and white in a society where notions of colour were firmly attached to the concept of free and servile.

\title{
The Nicole family
}

The Nicole family descend from Olivier Nicole, a French sailor who worked on commercial slave ships that journeyed between Nantes, Africa, Réunion and India; and Melanie, an Indian slave of François Piveteau. Nicole, who had a wife in France, met Melanie during one of his stays on Réunion and she became his mistress. Their first child, Célestin, was born in 1795 and their second, Auguste, in 1797. Two other children, Laurencine and Pierre-Charles dit Benoît, would follow. As their parents were not married, the children did not have a French family name and were thus brought up as Piveteau's slaves until their mother was freed in 1814. All the children except PierreCharles dit Benoît were emancipated with their mother. Curiously, the youngest son was signed over to Melanie as her slave, and he retained this status until 1827 when the governor signed an order permitting all people of colour who were effectively free to become officially free.

In 1820, after the ship he was on was captured by the English for illegal slave trading, Olivier Nicole settled in Réunion, living with Melanie in Saint-Denis where she had a little shop. In 1831, Olivier (aged sixty-seven) and Melanie (aged sixty-two) finally decided to legalise their union, marrying in Saint-Denis and recognising their three 
children, Célestin, Auguste and Pierre-Charles dit Benoît. ${ }^{14}$ At this point, the children took on their father's surname and passed into the 'white' population, becoming landowners with slaves of their own. Within their lifetimes, then, the Nicole children were variously classified as slaves, Affranchis and white. The colour of their skin was thus no barrier to belonging to any of the island's social groups.

\section{The abolition of slavery on Réunion}

The general emancipation of Réunion's slaves in 1848 had a huge impact on demographic and social development on the island. The sudden removal of the free labour provided by the slaves put sugar producers into a panic. This was assuaged to a certain degree by Sarda Garriga's order that all males freed in 1848, excepting those with a trade or a parcel of land, had to enter into an obligatory work contract with their former master. ${ }^{15}$ The supposed humanitarian grounds upon which this order was passed, namely to protect Affranchis from exploitation from their former master, prevent desertion of the workplace and keep public order by stopping vagrancy, could not hide the real agenda at play. ${ }^{16}$ Affranchis were understandably reluctant to return to the plantations and many escaped to the towns, became drifters or entered into fictitious engagements with Petits-Blancs (Fuma 2000). By 1851, most of the forced engagements had ended and plantation owners turned once again to foreign labour. The massive importation of indentured labourers from India $(80,000)$, Africa, the Comoros Islands and Madagascar (40,000) began in earnest (Fuma 2001). While some Affranchis continued to work as contract labourers on the plantations, most preferred to leave their former masters to work as artisans, labourers or domestics in the towns (Bourquin 2005: 141). But work was not always easy to find and, while some Affranchis had become landowners and were climbing the social ladder (Bourquin 2005: 146), others fell victim to extreme poverty and struggled to survive in the towns. Out of desperation, large numbers of women turned to prostitution and, as a result, syphilis became an increasing health issue in Réunion (Fuma 2000).

For the Petits-Blancs still possessing land on the coast, the end of slavery meant the end of any hope of maintaining their lands. The Métropole did not compensate them in a

\footnotetext{
${ }^{14}$ Presumably Nicole's French wife had died before then. Melanie's daughter, Laurencine, was not recognised and must have therefore had a different father.

${ }^{15}$ This order was extended to women the following year in response to plantation owners' complaints of a gross shortage of domestic labour (Fuma 2000).

${ }^{16}$ See Fuma (2001) for details.
} 
timely or appropriate way and many were consequently unable to afford to pay engagés to replace their slave labour. Most gave up, selling their land to the large landholders and heading up into the Hauts or into Saint-Denis. Those who remained, became more and more ostracised from 'white' society and devastatingly poor. The sugar crisis of the 1860s was the ultimate death knell for the few remaining Petits-Blancs of the Bas. ${ }^{17}$ At this point, some chose to move into the towns, others went up into the Hauts and a few elected to leave Réunion in search of greener pastures (Bourquin 2005: 138, 147-148).

Despite the continued métissage both in the Hauts, between the Petits-Blancs, Maroons and, from 1848, the Affranchis, and in the poor neighbourhoods of Saint-Denis, the Petits-Blancs clung on to what was becoming a progressively more obsolete view of social stratification. In Réunion, land had always been important to wealth and social status. As a landowner, one did not have to work and was therefore 'free' (and 'white'). According to Alexandre Bourquin, social rapports had also always been based on the opposition between black and white. Blacks represented slavery and work and whites represented liberty by virtue of possessing land (2005: 146). As the Petits-Blancs began losing their land, they steadfastly refused to work so as to preserve their status as white. The fact that some free people of colour were becoming landowners and, through hard work, were becoming wealthy, somewhat disrupted the logic of the Petits-Blancs, but for them working for a Grand Blanc meant renouncing their freedom. They vehemently rejected the imposition of the livret de travail, resisting the authorities' attempt to lump them together with the newly free, and the introduction of black indentured workers from India, Madagascar and Africa only reinforced their ever more distorted perception of freedom. Declining to work for the rich sugar barons, they were unable to adjust to a post-slavery sugar economy and found themselves excluded from their former social group (Bourquin 2005: 132, 147, 151). ${ }^{18}$

\section{Sugar workers in New Caledonia}

The sociohistorical factors outlined above give us some useful insights into the identities of the Réunionnais workers who chose to emigrate to New Caledonia. Given the extreme reluctance of the Petits-Blancs to work for the Grands Blancs in Réunion, it

\footnotetext{
${ }^{17}$ The Bas refers to the fertile coastal lands in Réunion.

${ }^{18}$ Towards the end of the nineteenth century, once the importation of indentured overseas workers had ended, some Petits-Blancs accepted to become sharecroppers on the rich planters' lands. Some even became sharecroppers on the lands of former slaves who had succeeded in working their way to the top of the social pyramid (Bourquin 2005: 151, 254).
} 
seems highly unlikely that they were among the sugar workers who arrived in New Caledonia with the wealthy sugar planters as engagés. While many of the engagés were Indian or 'Malabar,' my research into this population showed that it was far more heterogenous than previously thought (Speedy 2009). The registers of the État Civil and information in the local newspapers indicate that some engagés were Malagasy or African and their lack of surname (and often lack of known filiation) point towards them having been imported indentured labourers in Réunion who had either not finished their contract when their employer decided to emigrate or who had decided to recontract to accompany him to New Caledonia. A few examples include Antoine, an engagé of Evenor de Greslan in Dumbéa, described as an African of unknown filiation who arrived in New Caledonia in 1865 and who died in 1868, ${ }^{19}$ Antoine, Malagasy, engagé of Louis de Nas de Tourris whose filiation was unknown and who died in 1874 at the age of twenty ${ }^{20}$ and Sahary, Cafre, an engagé of Jouhault who in 1875 had been on the run for nearly two years from his employer (Le Moniteur de la Nouvelle-Calédonie, 8 December 1875). ${ }^{21}$

Alongside the Malagasy, African and Indian indentured workers, a number of Creoles are described as engagés. Le Moniteur de la Nouvelle-Calédonie, for instance, printed a list of indentured workers who had absconded from their place of work and were still at large in 1875. ${ }^{22}$ These included Henri-Alexandre Lachaise, Fortuné-Henri Lachaise, Gasparin Larose, Pierre Antoine and Pierre Ély, all of whom were engagés of de Tourris and whose 'caste' was described as Creole. Ernest Montrose, a Creole who had been employed by Boyer, was also on the list, as was Émile Célestin, a 'Bourbon’ who had worked for Laurie at Canala.

Who might these Creoles have been? In Réunion, all those born on the island, regardless of their ethnic makeup, were called Creoles. And this, all the way across the social spectrum — so the richest landowners were Creoles as were their Réunion-born slaves and so too were the Petits-Blancs and freed people of colour. During the nineteenth century, this appellation was not extended to recent Indian migrants or the Chinese

\footnotetext{
${ }^{19}$ DPPC EC NCL/NOUMEA/5 (1867-1868).

${ }^{20}$ DPPC EC NCL/NOUMEA/10 (1874).

${ }^{21}$ Cafre was a term employed in Réunion to designate slaves and later engagés from Africa (Nicole 1996: 31-31).

${ }^{22}$ The list was published on 8 December 1875 and a supplement to the list, which included Ernest Montrose, was published on 22 December 1875.
} 
(Nicole 1996: 32-35) so we can exclude these groups. As mentioned above, it is unlikely that the Petits-Blancs would have entered into an indentured arrangement with a Grand Blanc sugar planter as they would have perceived it as relinquishing both their freedom and social status. It is most likely, then, that the Creole engagés were freed people of colour.

This assertion is confirmed by checking the family names of the engagés against the lists of surnames attributed to freed slaves between 1832 and $1848 .^{23}$ These lists contain the surnames given to slaves by their masters upon their emancipation, allowing slaves, who until this point went by a single name only, to transmit a surname to their children. ${ }^{24}$ While most of the names on the lists are those attributed to freed slaves, a few belong to their spouses who may have been 'white' or freed people of colour. And, despite official instructions to slave owners to avoid giving freed slaves a surname that already existed in Réunion, some made errors. There were also surnames attributed to the newly free in 1848 that had been attributed to freed slaves in the past. ${ }^{25}$ These factors explain why old Réunionnais names such as Adam, Maillot and Robert appear on the freed slave surname lists. Some may represent spouse names, others may have been attributed to Affranchis either in error or simply due to a first name being chosen to act as a surname which was already in use.

Despite the fact that these lists are incomplete, as a number of the 1848 registers of emancipation 'disappeared,' and they do not take into account the names of slaves freed prior to 1832, they can be used to indicate the presence in New Caledonia of a significant number of Réunionnais from this particular social background. In Table 1 (see Appendix), in addition to identifying surnames given to Affranchis, I have indicated whether the name appeared in Ricquebourg’s dictionary of old Réunionnais family names. Even if we exclude the names that belonged to both ex-slave and 'white' populations, Table 1 demonstrates that a good portion of Réunionnais who immigrated to New Caledonia were Affranchis or descendants of freed slaves. In fact, of the Réunionnais family names I found in the registers of the État Civil in New Caledonia’s

\footnotetext{
${ }^{23}$ See Patronymes attribués aux anciens esclaves affranchis (1832-1848) on the Cercle généalogique de Bourbon website: http://www.cgb-reunion.org/les_bases/esclavages/esclaves.htm.

${ }^{24}$ Slaves freed prior to the 1830s usually transformed their first name into a surname that they bestowed on their children.

${ }^{25}$ This was especially the case with first names that slave owners decided would become the slave's family name, as this practice had been common among emancipated slaves from the start.
} 
southern communes or in published sources, 44 percent figured on the Affranchi surname lists. Given the large size of many Réunionnais families, the percentage of freed slaves and their descendants in the actual Réunionnais migrant population may well have been greater.

Interestingly, while the majority of the Affranchis of 1848 spurned a return to their former master's plantation, Sudel Fuma's research shows that on average around 15 percent of the indentured sugar workers in Réunion in 1858 were Affranchis (Fuma 1983: 532-33). Some of these experienced ex-slaves may have in turn migrated to New Caledonia to help set up the sugar industry in the early 1860s. However, the fact that the Creole runaway engagés described in Le Moniteur de la Nouvelle-Calédonie of 1875 were aged seventeen to twenty-four, illustrates that descendants of Affranchis probably represented a more important part of the immigration. ${ }^{26}$

It would seem, in the case of the younger engagés, that poverty and lack of prospects in Réunion drove them to accept an indentured contract that saw them return to conditions not dissimilar to the slavery their forebears had left behind. Perhaps it was seen as a stepping-stone to greater opportunities in a new land? Or maybe it was the only way to shake off the social exclusion that they felt in their native island as descendants of slaves? The story of Ernest Montrose gives us some insight into the life of one of these contract labourers.

\section{Ernest Montrose: Creole, engagé and vanilla planter}

Ernest Montrose was listed as an 'engagé déserteur' in Le Moniteur de la NouvelleCalédonie (22 December 1875). His description reads: ‘Ernest Montrose, Creole, aged twenty-four, 1.6 metres tall, missing his two upper front teeth, engagé of Boyer at Uaraï.' This brief, impersonal record sounds like a wanted poster or a description of a runaway slave and certainly piques the curiosity of a twentyfirst century reader. Who was this man and what became of him? Thanks to the extensive genealogical research undertaken by Pearl Montrose, his grandson's wife, we can fill in some of the blanks. ${ }^{27}$ Born in 1852 to Jean-Baptiste Montrose and Anne Josephi Andrèze, Ernest and his three

\footnotetext{
${ }^{26}$ With the exception of Pierre Ély, all of the other engagés' names figure among those attributed to freed slaves.

${ }^{27}$ I would like to sincerely thank Pearl Montrose for her generosity in sharing her research with me. Pearl kindly sent me birth, death and marriage certificates, census records, letters and photos of the Montrose and Florian families which have allowed me to recount something of the life of one of New Caledonia's Creole engagés.
} 
siblings were legitimised by their parents’ marriage in 1855. The Montrose family had been free for a few generations. ${ }^{28}$ His father was the son of Joseph Montrose and Marie Jeanne Azariste Montauban. The Montauban family were freed people of colour from Sainte Marie. Ernest's great-grandfather, Jean Jacques Montauban, was classified in the 1820 census as a habitant or small-scale planter who grew coffee, corn and rice and owned six slaves. Ernest's great-grandmother, Joseph Montrose's mother, was a slave called Eleanor. While Ernest was certainly a free man of colour, he was not an Affranchi of 1848. Indeed, his family had been landowners for quite some time. However, the economic pressure that came with the expanding sugar industry, followed by the sugar crisis of the 1860s, had a similar impact on the landowning free people of colour as it had on the Petit-Blancs.

It is not known why Ernest decided to enter into an indentured contract and migrate to New Caledonia. We can only imagine that his family lost their land and become impoverished. He was perhaps adventurous and willing to sacrifice five years of freedom for the chance at a better life in the Pacific. Whatever the case, his situation must have been desperate for him to become an engagé. By 1875, though, he was an engagé on the run. Whether he returned to Boyer's property to finish his contract remains undetermined.

At some time in the 1880s, Ernest made his way to Fiji where he leased some land from the government and set up a vanilla plantation, the first in Fiji. His trials and tribulations are set out in his fascinating correspondence with the government of Fiji. In his letters, we catch glimpses of the man he was. His first letters from 1887 show his determination to make something of himself by obtaining land to set up his plantation. He tells the governor of Fiji about his extensive experience growing vanilla in Réunion and describes his somewhat wretched current state. 'Since my arrival in Fiji,' he says, 'I have managed to find a few jobs and bring up my family. But today, in the current state of the colony, I find that I am reduced to poverty and am seeking any way to get out of this miserable position. ${ }^{29}$ His solution is to obtain for rent, as cheaply as possible, 'a few acres in the vicinity of Suva' so that he could finally ‘find a useful occupation' and

\footnotetext{
${ }^{28}$ His mother was the illegitimate daughter of Pen Andrèze who was likely to have been a freed slave.

${ }^{29}$ Ernest Montrose to the Governor of Fiji, 21 November 1887. Original letter in French. The family that Ernest mentions in this letter is certainly not the one he would have with Mathilde Florian ten years later. He seems to have had a prior relationship with another woman and had children with her. Who they were and what became of them is unknown.
} 
'work for the good of the colony. ${ }^{30}$ In February 1888, the government granted Ernest fifteen acres of land in Suva to be held by him as a tenant from year to year. ${ }^{31}$

In 1892, Ernest's vanilla plantation was up and running but he had got himself into debt. His request that the government lease him the land for twenty-one years and release him from paying his rental arrears was firmly rejected by the Commissioner of Lands. ${ }^{32}$ Refusing to give up, in his reply Ernest writes proudly of his achievements in setting up the first vanilla plantation in Fiji and points out to the governor that he is not a refugee, perhaps in an attempt to distance himself from the 'Malabar' ex-engagés who fled New Caledonia for Fiji in the 1880s (Speedy 2009: 138-139). ${ }^{33}$ Concerned for the welfare of his family, for whom he could not provide if forced to pay back the debt, his letters get progressively more poignant. In 1897, he ultimately asks the governor to accord him his lands 'in title of cession,' a request that was again steadfastly refused. ${ }^{34}$

Undoubtedly a Creole speaker, Ernest wrote his first letters in very good French, showing that he had been educated. Interestingly, after having lived in Fiji for a number of years, Ernest began to write in English. The very French flavour of the English letters (French syntax, style and word-for-word translation of set expressions) indicates that Ernest had taught himself English (which, in one letter, he professed not to speak well as he was 'of French Nation'). ${ }^{35}$ Despite all his scrapes and misfortunes, Ernest was, it seems, an intelligent man.

In 1897, while he was fighting for his plantation, he married Mathilde Florian. Ernest was forty-four and Mathilde was sixteen and pregnant. What had become of his other family is not known. Like Ernest, Mathilde came from a family of Affranchis from Réunion. Born in Nouméa to Gaston Florian, carpenter, and Julia Festin, both Réunionnais of freed slave descent, Mathilde had arrived in Fiji with her family in the mid 1880s. In 1898, George Stanislaus Montrose was born to Mathilde and Ernest. There is no information regarding what happened to Ernest's plantation or to his

\footnotetext{
${ }^{30}$ Ernest Montrose to the Governor of Fiji, 21 November 1887. Original letter in French.

${ }^{31}$ The Colonial Secretary of the Colony of Fiji to Ernest Montrose, 16 February 1888.

32 Ernest Montrose to the Commissioner of Lands, 31 August 1892 and the Commissioner of Lands to Ernest Montrose, 21 September 1892.

${ }^{33}$ Ernest Montrose to the Governor of Fiji, 17 November 1892.

${ }^{34}$ Ernest Montrose to the Governor of Fiji, 30 August 1897 and the Colonial Secretary to Ernest Montrose, 4 September 1897.

${ }^{35}$ Ernest Montrose to the Governor of Fiji, 30 August 1897.
} 
relationship with his young wife. By 1908, Mathilde had left Fiji and Ernest and was living in New Zealand with George. In 1908, she gave birth to another son, William Clement Montrose, in Auckland. ${ }^{36}$ Mathilde then married Edgar Reginald Way in 1921. William took his stepfather's name once his mother had remarried. George Montrose worked as a printer in Auckland. He married in 1923, had nine children and his numerous descendants are scattered around New Zealand. ${ }^{37}$ Some of the Florian family remained in Fiji, but most ended up in New Zealand or Australia.

Mathilde had given Ernest's date of death as 1908 on her marriage certificate to Edgar Way. This was, however, a fabrication. Ernest had left Fiji and was living in Tahiti by the early 1900s. He remarried in 1903 or 1904 and died at seventy-seven years of age in 1929. His death certificate records him as a cultivateur (farmer) born in Réunion. ${ }^{38}$ While we can never know whether Ernest ultimately found his bonheur in his selfimposed exile, his story highlights the movement of people and technology from the Indian Ocean to the Pacific. As we learn from Ernest's letters, he had considerable experience growing vanilla in Réunion. If the family vanilla plantation was lost during the sugar crisis, the knowhow was transported with Ernest to New Caledonia and then on to Fiji and Tahiti. For Ernest, the decision to become an engagé was perhaps not the worst one for he was eventually able to live as a free man again and pioneer vanillagrowing in Fiji.

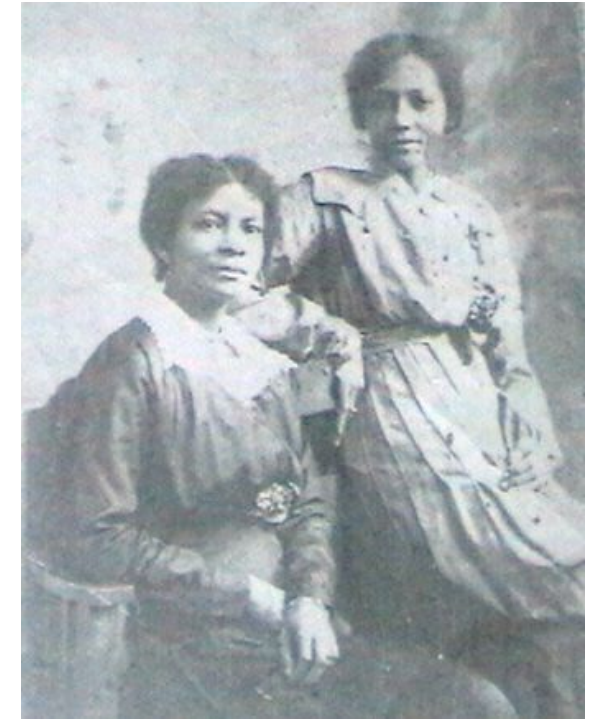

Mathilde and Maria Florian (c) Pearl Montrose, Hamilton, New Zealand, c. 1900.

\footnotetext{
${ }^{36}$ Although he carried Ernest's name, it is unlikely Ernest was his father.

${ }^{37}$ His eldest son, George, was the late husband of Pearl Montrose.

${ }^{38}$ Pearl Montrose, personal communication, 31 July 2010.
} 


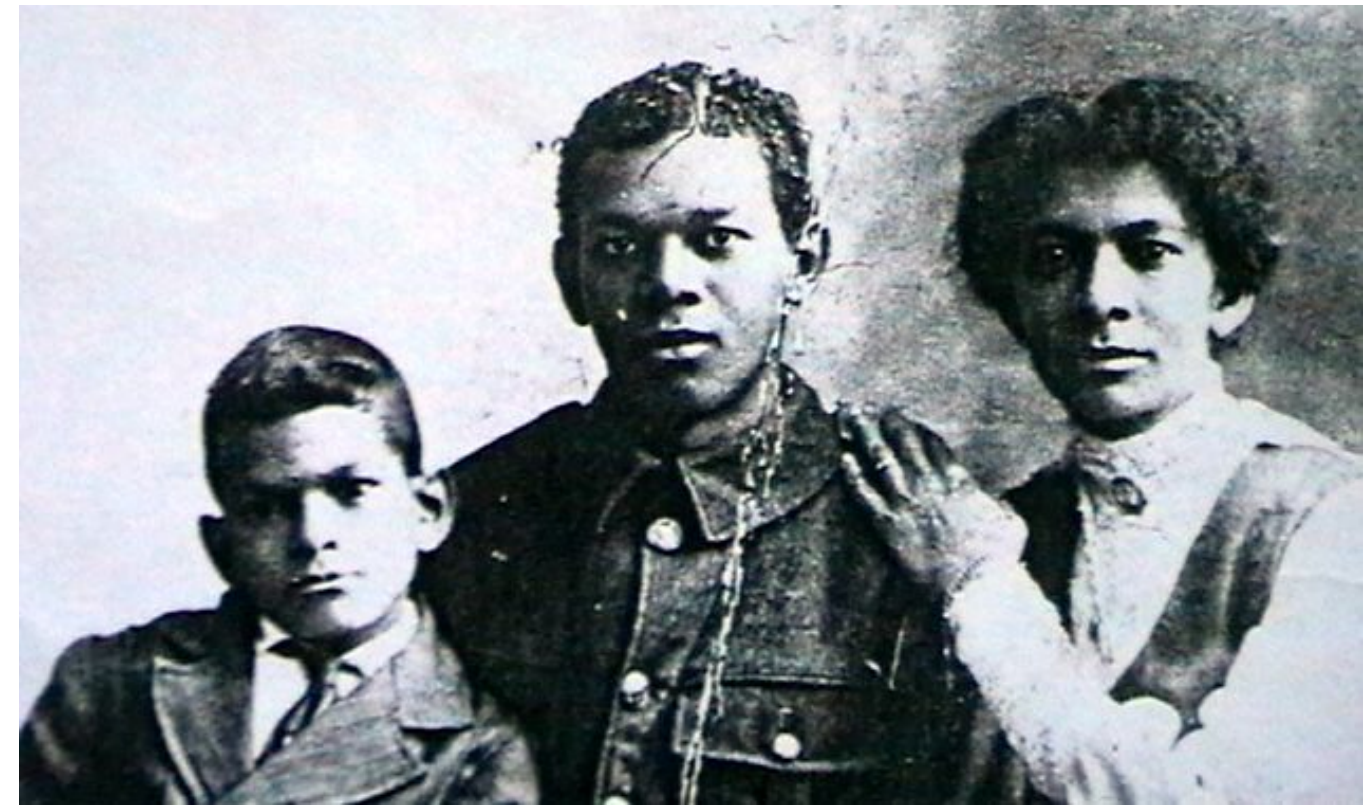

William, George and Mathilde Montrose (née Florian)

(C) Pearl Montrose, Hamilton, New Zealand, c. 1915.

\section{Land: the key to success for many Creole immigrants to New Caledonia}

Unlike Ernest Montrose, other Réunionnais workers, a good number of whom were free people of colour, settled permanently in New Caledonia. Many shared Ernest's agricultural background and it was often through hard work and land ownership that they were able to improve their destinies. One well-known example is the Kabar family, famous for introducing lychees to New Caledonia. Jolimont Kabar and his wife Héloïse Nézet arrived in the colony in 1868 with their nine children. Jolimont was listed as having no profession in the passenger list of the Aveyron ${ }^{39}$ but, settling in Nouméa, he worked as a pit sawyer and day labourer. ${ }^{40}$ Héloïse, like a number of other Réunionnaises in Nouméa, helped supplement the family income through her work as a seamstress. ${ }^{41}$ The family continued to grow and the Kabars moved to Ponérihouen before obtaining some one hundred acres in Houaïlou. There Jolimont planted fruit and coffee and, although conditions were difficult and the work was backbreaking, he managed to provide for his eighteen children and develop his lands. Jolimont Kabar died aged ninety-six and his descendants represent one of the largest families of New Caledonia (Angleviel \& Milin 2004: 14).

\footnotetext{
${ }^{39}$ Le Moniteur de la Nouvelle-Calédonie, 31 May 1868, no. 453.

${ }^{40}$ DPPC EC NCL/NOUMEA/5 (1867-1868), DPPC EC NCL/NOUMEA/5 (1869-1870).

${ }^{41}$ DPPC EC NCL/NOUMEA/5 (1869-1870). The occupation of seamstress was extremely popular among the female Affranchi population in Réunion (Fuma 2000) and in Mauritius (Allen 2005: 190).
} 
The Mitride family, too, were descendants of freed slaves who settled in New Caledonia and became integrated into white society through landownership. Charles Mitride, who was a coal seller in Saint-Denis, his wife, Marie-Julie Angèle Zamor, and their son, Charles Ludovic, arrived in New Caledonia in 1872. After initially working in the sugar industry, the family lost everything in 1878 during the Kanak uprising. In the early 1880s, with the compensation they had received, they bought land at Sarraméa where they raised their twenty-one children. Reputed for introducing both the flame tree and the kaffir lime to New Caledonia, the Mitrides also put down their roots in their new Pacific home, with their descendants forming another of New Caledonia's largest families. $^{42}$

Other workers lived on and around the sugar-growing concessions in Dumbéa and Mont-d'Or where land was leased to settlers in a sharecropping arrangement. Some were Affranchis and others were Petits-Blancs. The Marists at Saint-Louis allowed some 'black or white' families to settle on the mission lands and sugar planters Arthur Duboisé and Numa Joubert advertised small farms for lease on their respective properties for sugar cane cultivation. ${ }^{43}$ The idea was that the sharecroppers would then supply the sugar mills at Nimba and Koé.

A few years after the death of sugar grower Ferdinand Joubert, his property at Koé was put up for sale, including the lands and chattels leased to five sharecroppers, two of whom were Petits-Blancs from Réunion, one a former Malabar engagé and the wife of another a Réunionnaise free person of colour. ${ }^{44}$ While the Petits-Blancs were unlikely to have been engagés for the large concession owners, the opportunity to grow sugar on their own leased plot of land appeared to be more acceptable. Indeed, the New Caledonia experience foreshadowed the colonat partiaire in Réunion that would see some Petits-Blancs accepting to work as sharecroppers on the sugar plantations by the end of the nineteenth century (Bourquin 2005: 240-242).

For the Petits-Blancs and the Affranchis, working on the land and leasing land were two important avenues towards land ownership, the key to social success in New Caledonia.

\footnotetext{
${ }^{42}$ For details see Delathière (2004: 91) and information on Charles Mitride on the Geneanet website: http://gw5.geneanet.org/index.php3?b=trigalleau\&lang=fr;p=charles;n=mitride.

${ }^{43}$ See Ehrhart (1994 : 27), Le Moniteur de la Nouvelle-Calédonie, 5 June 1872, no. 663 and Le Moniteur de la Nouvelle-Calédonie, 22 October 1873, no. 735.

${ }^{44}$ See Speedy (2007a: 77-80) for details.
} 
In the registers of the État Civil of southern New Caledonia, the occupations of farmer and landowner were most prevalent, especially out of the capital. Planters and sugar growers were also jobs for Réunionnais in the rural areas (Speedy 2007a: 108-10). With some exceptions, notably in administrative roles in Nouméa, ${ }^{45}$ the Petits-Blancs favoured farming, replicating their agricultural activities back home. The descendants of the Affranchis, however, could be found in both rural and urban contexts.

\section{Tradesmen and low-skilled workers}

Alongside the agricultural occupations in the registers of the État Civil, Réunionnais were listed as being employed in trades and low-skilled jobs in Nouméa as well as on the sugar concessions. They were carpenters, joiners, coopers, launderers, road menders, stone cutters, cooks, day labourers, mechanics, fishermen, seamstresses and milliners, to name but a few of their professions. If the family names of some of these workers indicate that they were most likely Petits-Blancs, the majority appear to be from the freed slave group.

In Réunion, Creole slaves were often taught trades that set them up for a life outside the plantation if they were freed. After the general emancipation of 1848, slaves worked in trades or in blue-collar jobs, avoiding whenever possible a return to the master's property. As Helen Hintjens (2003: 109) observes, '[a] few hours of work a day as a carpenter, mason, seamstress, office clerk, blacksmith, baker, or selling goods on the road could yield a better return for the former slaves and their children than a month's hard plantation labor.' One of the most popular jobs for freed slave women was that of seamstress (Fuma 2000). The possession of a trade and the willingness to work meant that Affranchis and Petits-Blancs were able to respond to New Caledonia's need for labour-agricultural, industrial and commercial.

\section{A new colony and a new status}

During the 1860s, the freed slave and poor white communities of Réunion were facing increasing marginalisation and great misery. As new French citizens, the Affranchis and their descendants were still living with the stigma of being ex-slaves and, despite the on-going métissage, many continued to be treated as second-class citizens (Hintjens 2003: 108). The Petits-Blancs were progressively moving further away from their

\footnotetext{
${ }^{45}$ See Speedy (2007a: 111) for details.
} 
former social status as landowning whites and becoming ever more impoverished. The situation for both groups was dire. The opportunity to migrate to a new colony, desperately in need of settlers, entrepreneurs and workers, was one that some of the more adventurous souls must have seen as an attractive option.

Bringing with them expertise in a number of industries and agricultural enterprises as well as technical skills, the Affranchis and Petits-Blancs of Réunion were mostly prepared for a life of hard work, helping to get a new colony moving forward in exchange for a better social position. Some, such as Ernest Montrose and the Florian family, moved on to establish themselves in other Pacific lands, a few failed to lead suitably industrious and law-abiding existences and were repatriated, but most Réunionnais stayed. Aside from escaping from poverty, the move to the Pacific allowed two groups on the outer in their home island to become members of New Caledonia's free 'white' population and, over the years, their descendants have mixed with people of diverse backgrounds to form an important part of the Caldoche population.

\section{Appendix}

Table 1: Surnames of Réunionnais immigrants to New Caledonia in the nineteenth century and their social origins ${ }^{46}$

\begin{tabular}{|l|l|l|l|}
\hline Family Name & $\begin{array}{l}\text { Place of residence in } \\
\text { 19th century New } \\
\text { Caledonia }\end{array}$ & $\begin{array}{l}\text { Name listed as a } \\
\text { surname attributed to } \\
\text { freed slaves in Réunion } \\
\mathbf{1 8 3 2 - 1 8 4 8}\end{array}$ & $\begin{array}{l}\text { Name listed in } \\
\text { Ricquebourg's } \\
\text { dictionary of family } \\
\text { names in Réunion } \\
\mathbf{1 6 6 5 - 1 7 6 7}\end{array}$ \\
\hline Adam & Dumbéa & Yes & Yes \\
\hline Adam de Villiers & Dumbéa & & Yes \\
\hline Adèle & $\begin{array}{l}\text { Dumbéa (Koé), } \\
\text { Nouméa }\end{array}$ & Yes & \\
\hline Adrien & Nouméa & Yes & Yes \\
\hline $\begin{array}{l}\text { Adrisse- } \\
\text { Desruisseaux }\end{array}$ & Nouméa & & \\
\hline Aillaud+ & ? & & Yes \\
\hline Albaret & Canala & & \\
\hline Alizart & Nouméa &
\end{tabular}

\footnotetext{
${ }^{46}$ This table was compiled from information contained in the registers of the État Civil of Nouméa, Dumbéa, Mont-d'Or and Païta (1863-1899) that were available for consultation at the Centre des Archives d'Outre-Mer, Aix-en-Provence in 2005 and 2008 (see note 4). Other names of Réunionnais present in New Caledonia in the nineteenth century were found in the following printed sources: Le Moniteur de la Nouvelle-Calédonie *, Chevalier (1997) +, O'Reilly (1953)^, and Delathière (2004) \#. The freed slave names were sourced from Patronymes attribués aux anciens esclaves affranchis (18321848): http://www.cgb-reunion.org/les_bases/esclavages/esclaves.htm and 'old' Réunionnais family names were found in Ricquebourg (1976).
} 


\begin{tabular}{|c|c|c|c|}
\hline Amedée+ & ? & Yes & \\
\hline Amourdon+ & ? & & \\
\hline Antoine & Dumbéa (Nimba, Koé) & Yes & \\
\hline Armand & Mont-d'Or & Yes & \\
\hline Balmain & Dumbéa (Koé) & & \\
\hline Bataille & Nouméa & Yes & \\
\hline Beaucourt & Nouméa & & \\
\hline Beck+ & $?$ & & \\
\hline Bellanger+ & ? & & \\
\hline Berconet & Nouméa & & \\
\hline Bernier & Dumbéa, Nouméa & & \\
\hline Berrouet & Nouméa & & \\
\hline Bertin & Nouméa & Yes & Yes \\
\hline Botari+ & $?$ & & \\
\hline Boucher & Nouméa & & Yes \\
\hline Bouillier^ & $?$ & & \\
\hline Bourgine+ & ? & & \\
\hline Bouvier & $?$ & Yes & \\
\hline $\begin{array}{l}\text { Bouyé / Bouyer / } \\
\text { Boyé }\end{array}$ & Dumbéa, Nouméa & & Yes \\
\hline Boyer & Mont-d’Or, Nouméa & Yes & Yes \\
\hline Brajeul & Nakéty & & \\
\hline Brevant + & Nakéty & Brevans & \\
\hline Broume+ & ? & & \\
\hline Brulle+ & ? & & \\
\hline Bruguier & Nouméa & & \\
\hline Brunet + & $?$ & & \\
\hline Buttié & Nouméa & & \\
\hline Cabrié & $\begin{array}{l}\text { Mont-d’Or (La } \\
\text { Coulée) }\end{array}$ & & \\
\hline Cadet+ & ? & Yes & Yes \\
\hline Cahen & Nouméa & & \\
\hline Calmel & Païta & Yes & \\
\hline Carré & Nouméa & & Yes \\
\hline Casineny+ & ? & & \\
\hline Catan & Dumbéa (Koé) & & \\
\hline Cazeaux & Nouméa & & Yes \\
\hline Cayla $+^{+}$ & $?$ & & \\
\hline Cédrat & Nouméa & Yes & \\
\hline Célestin & Canala & Yes & \\
\hline Célières & Nouméa & & \\
\hline Charlot & Païta & Yes & \\
\hline Chatel+ & ? & & \\
\hline Chauvette & Nouméa & & \\
\hline Chevalier & Ouaménie & Yes & Yes \\
\hline Clain & Dumbéa (Nimba, Koé) & Yes & Yes \\
\hline Clémenceau & Nouméa & & \\
\hline Colette+ & $?$ & Yes & \\
\hline Cologon & Ouaménie & Yes & \\
\hline Combien+ & $?$ & & \\
\hline Compins+ & ? & & \\
\hline Cybou & Nouméa & & \\
\hline Dalleau & Nouméa & Yes & Yes \\
\hline Dargaud & Nouméa & Yes & \\
\hline Darius & Nouméa & Yes & \\
\hline De Balmann & Nouméa, Ponerihouen & & Yes \\
\hline De Gaillande & Nouméa & & \\
\hline De Greslan & Dumbéa (Nimba), & & Yes \\
\hline
\end{tabular}




\begin{tabular}{|c|c|c|c|}
\hline & Nouméa & & \\
\hline De Keranval-Aimé & Dumbéa, Nouméa & & Yes \\
\hline De Kervéguen & Ouaménie & & \\
\hline De Nas de Tourris & Ouaménie, Nouméa & & Yes \\
\hline De Villeneuve & Dumbéa (Yahoué) & & \\
\hline De Langlard & Païta & & \\
\hline Delval & Dumbéa & & \\
\hline Denage & Nouméa & Yes & \\
\hline Denis & $\begin{array}{l}\text { Mont-d'Or (Saint- } \\
\text { Louis) }\end{array}$ & Yes & \\
\hline Dercourt & Nouméa & Yes & \\
\hline Deschamps & Nouméa & Yes & \\
\hline Desjardins & Nouméa & & Yes \\
\hline Desmaret ${ }^{+}$ & $?$ & & \\
\hline Desruisseaux & Nouméa & & \\
\hline Devaud & ? & & \\
\hline Dijou & $\begin{array}{l}\text { Mont-d'Or, Saint } \\
\text { Vincent, Nouméa }\end{array}$ & & \\
\hline Diomat & Ouaménie & & Yes \\
\hline Diovada+ + & ? & & \\
\hline Doussaniau+ & ? & & \\
\hline Douyère & Païta & & Yes \\
\hline Dubain & Nouméa & & Yes \\
\hline Duboisé & Dumbéa (Nimba) & & \\
\hline Dubuisson+ & ? & & Yes \\
\hline Durand & Nouméa & Yes & \\
\hline Elphège & Nouméa, Ouéga & Yes & \\
\hline Ély & Ouaménie & & \\
\hline Equerre+ & $?$ & Yes & \\
\hline Falais & Nouméa & & \\
\hline Faucher & Dumbéa & Yes & \\
\hline Fayet & Ouéga & Yes & \\
\hline Ferrand + & $?$ & Yes & Ferand \\
\hline Festin+ & ? & Yes & \\
\hline Firman & Dumbéa (Koé) & Yes & \\
\hline Florian & Nouméa & Yes & Yes \\
\hline Florimond & Nouméa & Yes & \\
\hline Foucher & Nouméa & Fouchey & \\
\hline Frias & Nouméa & Yes & \\
\hline Fritzgerald+ & ? & & \\
\hline Fulbert+ & ? & Yes & \\
\hline Fulet & Nakéty & & \\
\hline Fullet & ? & Yes & \\
\hline Galland & Houagape & Yes & \\
\hline Garçon & Nouméa & Yes & \\
\hline Gezat & Houagape & & \\
\hline Gillet + & $?$ & & \\
\hline Gillot (de) l'Étang & Poindimié & & Yes \\
\hline Gisnet & Nouméa & Yes & \\
\hline Gondin+ & ? & & \\
\hline Goudin & $\begin{array}{l}\text { Nouméa (Vallée du } \\
\text { Tir) }\end{array}$ & & \\
\hline Gouët & Dumbéa, Nouméa & & \\
\hline Gouthier & Nouméa & & \\
\hline Grandidier & $?$ & Yes & \\
\hline Gravini+ & ? & & \\
\hline Grenier & $\begin{array}{l}\text { Dumbéa (Koé), } \\
\text { Nouméa }\end{array}$ & & Yes \\
\hline
\end{tabular}




\begin{tabular}{|c|c|c|c|}
\hline Grondin & Nouméa & Yes & Yes \\
\hline Guerin+ & ? & Yes & Yes \\
\hline Guichard & Nouméa & Yes & Yes \\
\hline Guilloteau & Nouméa & & \\
\hline Gustave & ? & Yes & \\
\hline Hacquard & Mont-d'Or & & \\
\hline Héros & $\begin{array}{l}\text { Nouméa (Vallée } \\
\text { Montravel) }\end{array}$ & Yes & $\begin{array}{l}\text { Yes (but the line ended in } \\
1794 \text { ) }\end{array}$ \\
\hline Heuvrond & Nouméa & & \\
\hline Hopts / Ops & Dumbéa (Nimba, Koé) & & \\
\hline Huet+ + & ? & & Yes \\
\hline Imbault & Nouméa & & \\
\hline Isnard & Nouméa & & \\
\hline Jagda & Nouméa & & \\
\hline Jeamissot + & ? & & \\
\hline $\begin{array}{l}\text { Jean-Baptiste dit } \\
\text { Doudoute }\end{array}$ & Nouméa & Yes & \\
\hline Jolibois+ + & ? & Yes & \\
\hline Jonquet & Nouméa & & \\
\hline Joson & ? & Yes & \\
\hline Kabar & Nouméa, Ponerihouen & Yes & \\
\hline Kichenin & $\begin{array}{l}\text { Dumbéa (Koé), } \\
\text { Nouméa (Vallée des } \\
\text { Colons) }\end{array}$ & Yes & \\
\hline Laborie+ + & ? & Yes & \\
\hline Lachaise & Ouaménie & Yes & \\
\hline Lafargue & Nouméa & Yes & \\
\hline Lamaison & Ouaménie & & \\
\hline Lamarque+ + & ? & Yes & \\
\hline Larose & Ouaménie & Yes & \\
\hline Latchimy & Dumbéa (Koé) & & \\
\hline Lathumie & Nouméa, Dumbéa & & \\
\hline Latouche & Nouméa & Yes & \\
\hline Lauratet & Nouméa & & \\
\hline Lebon+ & ? & Yes & Yes \\
\hline Lecomte+ & $?$ & Yes & Yes \\
\hline Legac+ & ? & & \\
\hline Le Roy & Nouméa & Yes & \\
\hline Lebihan / Le Bihan & $\begin{array}{l}\text { Mont-d'Or (Saint- } \\
\text { Louis), Nouméa }\end{array}$ & & Yes \\
\hline Lepervenche & Ouaménie & & \\
\hline Lepeut & Houagape (Wagap) & & \\
\hline Le Richard+ & $?$ & & \\
\hline Leriche / Le Riche & Nouméa, Dumbéa & Yes & Yes \\
\hline Lorette & Nouméa & Yes & \\
\hline Louvet & Dumbéa (Koé) & & \\
\hline $\begin{array}{l}\text { Magnien de } \\
\text { Magnienville }\end{array}$ & Nouméa & & \\
\hline Maillet+ & ? & & Yes \\
\hline Maillot & Dumbéa & Yes & Yes \\
\hline Maillou+ & ? & & \\
\hline Malignon+ & $?$ & & \\
\hline Maradan & Nouméa & Yes & \\
\hline Marchand & Nouméa & Yes & Yes \\
\hline Marcus & Nouméa & Yes & \\
\hline Marsou+ + & ? & & \\
\hline Martin+ & ? & Yes & \\
\hline Maurin+ & ? & Yes & \\
\hline
\end{tabular}




\begin{tabular}{|c|c|c|c|}
\hline Mayana / Mayanna & Dumbéa & Mayanne & \\
\hline Médéries & Dumbéa (Koé) & & \\
\hline Menon & Nouméa & & \\
\hline Michel & Nouméa & Yes & Yes \\
\hline Micholin & ? & & \\
\hline Miquel+ & $?$ & Yes & \\
\hline Mitride\# & Sarraméa & Yes & \\
\hline Montard & Nouméa & & \\
\hline Montolard+ & $?$ & & \\
\hline $\begin{array}{l}\text { Montroze / } \\
\text { Montrose }\end{array}$ & Uaraï & Yes & \\
\hline Mourland+ & $?$ & & \\
\hline Murch & Nouméa & & \\
\hline Muret+ & $?$ & Yes & \\
\hline $\mathrm{Nau}$ & Canala & & \\
\hline Nègre & Nouméa & & \\
\hline Nézet & Nouméa, Ponerihouen & Yes & \\
\hline Nolet + & ? & & \\
\hline Orthasie & $\begin{array}{l}\text { Dumbéa (Tonghoué), } \\
\text { Nouméa }\end{array}$ & Orthésie & \\
\hline Ovide & Ouaménie & Yes & \\
\hline Ozénor & Nouméa & & \\
\hline$\overline{\text { Ozoux }}$ & $\begin{array}{l}\text { Dumbéa (Koé, Koutio- } \\
\text { Kouéta), Nouméa }\end{array}$ & & Yes \\
\hline Patché & $\begin{array}{l}\text { Dumbéa (Koé), } \\
\text { Nouméa }\end{array}$ & Patchez & \\
\hline Patrick+ & ? & Yes & \\
\hline Paul & Dumbéa & Yes & \\
\hline Payandy & Nouméa & & \\
\hline Payet & Dumbéa, Nouméa & & Yes \\
\hline Péguillet & Nouméa & & \\
\hline Perchard+ & ? & & \\
\hline Pierrette+ & ? & & \\
\hline Pietri+ & ? & Yes & \\
\hline Pillegrain+ & ? & & \\
\hline Piveteau & $\begin{array}{l}\text { Nouméa (Vallée } \\
\text { Montravel) }\end{array}$ & & \\
\hline Pomadère & Nouméa & Pomader & \\
\hline Pouget + & $?$ & & \\
\hline Poutes & Païta & & \\
\hline Prichenin & Mont-d'Or & & \\
\hline Ragot+ & ? & Yes & \\
\hline Ramin / Ramain & Dumbéa & & \\
\hline Rapadzi+^ & Nouméa, Thio & & \\
\hline Rayandi & Nouméa & & \\
\hline Raynaud & Nouméa & & \\
\hline Renaud & Mont-d'Or & Yes & \\
\hline Revercé^ & Thio, Nouméa & & \\
\hline Ricquebourg & Dumbéa & & Yes \\
\hline Rivet & Nouméa & Yes & \\
\hline Robert & Nouméa & Yes & Yes \\
\hline Rochard+ & $?$ & Yes & \\
\hline Roland + & ? & Yes & \\
\hline Rolland+ & ? & Yes & \\
\hline Routier* & Ouaménie & Yes & \\
\hline Routier de Grandval & Poya & & Yes \\
\hline Sabry+ & $?$ & & \\
\hline Samson+ & ? & Yes & \\
\hline
\end{tabular}




\begin{tabular}{|c|c|c|c|}
\hline Sautron & ? & Yes & Yes \\
\hline Seisset+ + & $?$ & & \\
\hline Senonge+ + & ? & & \\
\hline Simon+ & ? & Yes & \\
\hline Stera + & $?$ & & \\
\hline St Lys & Nouméa & Yes & \\
\hline Sylvestre & Nouméa & Yes & \\
\hline Talon & Nouméa & Yes & \\
\hline Taochy+ & ? & & \\
\hline Tardivel & Nouméa & Yes & Yes \\
\hline Tassau+ & $?$ & & \\
\hline Tauzin & Nouméa & & \\
\hline Teissier+ & ? & & \\
\hline Tendrias+ & ? & & \\
\hline $\begin{array}{l}\text { Thibault de } \\
\text { Chanvalon }\end{array}$ & Nouméa & & \\
\hline Tournier & ? & & \\
\hline Turpin^ & ? & Yes & Yes \\
\hline Vaubois & Nouméa & & \\
\hline Vellon & Nouméa & & \\
\hline Venant & Nouméa & Yes & \\
\hline Vergoz & Nouméa & & Yes \\
\hline Verite+ + & $?$ & & \\
\hline Vézard / Vézart+ & $?$ & & \\
\hline Victor+ & & Yes & \\
\hline Vigneron+ & & Yes & \\
\hline Vincent & Dumbéa, Nouméa & Yes & Yes \\
\hline Virte / Wirth & Païta & & \\
\hline \multicolumn{4}{|l|}{ Vitorin+ } \\
\hline Vivien+ & & Yes & \\
\hline Volsant + & & Yes & \\
\hline Vlody & Nouméa & Yes & \\
\hline \multicolumn{4}{|l|}{ Wagner+ } \\
\hline Zacharie & Nouméa & Yes & \\
\hline Zamor\# & Sarraméa & Yes & \\
\hline
\end{tabular}

\section{Reference List}

Allen, R.B. 2005, 'Free Women of Colour and Socio-Economic Marginality in Mauritius, 1767-1830,' Slavery and Abolition, vol. 26, no. 2: 181-97.

Angleviel, F. \& Milin, Y. (eds) 2004, Une histoire en 100 histoires: l'histoire calédonienne à travers 100 destins hors du commun. Bambou, Nouméa.

Barassin, J. 1978, Mémoire pour servir à la connoissance particulière de chacun des habitans de l'isle de Bourbon / Antoine Boucher. L'île Bourbon et Antoine Boucher, 1679-1725 au debut du XVIIIe siecle / par Jean Barassin. Association des Chercheurs de l'Océan Indien, Aix-en-Provence.

Bollée, A. 2007, Deux textes religieux de Bourbon du 18e siècle et l'histoire du créole réunionnais. Battlebridge, United Kingdom \& Sri Lanka.

Bourquin, A. 2005, Histoire des Petits-Blancs de la Réunion XIX -début XX $X^{e}$ siècle. Karthala, Paris.

Cercle généalogique de Bourbon. Patronymes attribués aux anciens esclaves affranchis (1832-1848). Online, available: http://www.cgb-Réunion.org/les_bases/esclavages/esclaves.htm (Accessed January 1 2012).

Chaudenson, R. 1974, Le lexique du parler créole de la Réunion. Honoré Champion, Paris. 1992, Des îles, des hommes, des langues. Essai sur la créolisation linguistique et culturelle. L'Harmattan, Paris. 2003, La créolisation: théorie, applications, implications. L'Harmattan, Paris.

Chevalier, L. 1997, Les Bourbonnais de Nouvelle-Calédonie: l'arrivée des premiers Réunionnais sur le 
Caillou. L’amicale des Réunionnais et des amis de la Réunion, Nouméa.

Delathière, J. 2004, La Foa 120 ans d'histoire municipale. Ultimo, Auckland.

Delignon, L. 1898, Les alienations de terres et la colonisation libre agricole en Nouvelle-Calédonie Challamel, Paris.

Dépôt des Papiers Publics des Colonies Etat Civil (DPPC EC) for Nouméa, Païta, Dumbéa and Montd’Or, Centre des Archives d’Outre-Mer, Aix-en-Provence.

Ehrhart, S. 1994, 'Quelques réflexions concernant la genèse du tayo en Nouvelle-Calédonie et discussion des éventuels apports venant de l’extérieur, notamment du créole réunionnais,' unpublished manuscript.

Fuma, S. 1983, 'L’homme et le sucre à la Réunion: 1827-1862,' unpublished Ph.D. thesis, Université d'Aix-en-Provence.

1998, 'L’esclavage et le métissage, l’exemple d’une famille réunionnaise au XIXème siècle,' in Regards croisés sur l'esclavage 1794-1848, (eds) Jean-Marie Desport et al.,Somogy, Éditions d'arts, Paris, 114-18.

2000, 'Femmes et liberté à la Réunion après l’abolition de l’esclavage,' Conference paper presented at 'La femme et les sociétés pluriculturelles de l’Océan Indien, Université de la Réunion, Saint-Denis, 27-30 November. Online, available: http://www.historun.com/run/Pub/FEMMES_ET_LIBERTE.rtf (Accessed January 1 2012). 2001, 'Le servilisme à la place du concept d'engagisme pour définir le statut des travailleurs immigrés ou affranchis après l'abolition de l'esclavage en 1848.' Online, available:

http://www.historun.com/run/Pub/Le_servilisme.aspGeneanet:http://gw5.geneanet.org/index.php3? $\mathrm{b}=$ trigalleau\&lang=fr; $\mathrm{p}=$ charles; $\mathrm{n}=$ mitride (Accessed January 1 2012).

Hintjens, H. 2003, 'From French Slaves to French Citizens: the African Diaspora in Réunion Island,' in The African Diaspora in the Indian Ocean, (eds) S. de S. Jayasuriya \& R. Pankhurst, Africa World Press, Trenton \& Asmara, 99-121.

Le Moniteur de la Nouvelle-Calédonie 1864, Projet d’émigration de la Réunion vers la NouvelleCalédonie, 6 November, no. 267.

Le Moniteur de la Nouvelle-Calédonie, 1868, 31 May, no. 453.

Le Moniteur de la Nouvelle-Calédonie, 1870, 28 August, no. 570.

Le Moniteur de la Nouvelle-Calédonie, 1872, 5 June, no. 663.

Le Moniteur de la Nouvelle-Calédonie, 1872, 4 September, no. 676.

Le Moniteur de la Nouvelle-Calédonie, 1872, 13 November, no. 686.

Le Moniteur de la Nouvelle-Calédonie, 1873, 22 October, no. 735.

Le Moniteur de la Nouvelle-Calédonie, 1875, 8 December, no. 846.

Le Moniteur de la Nouvelle-Calédonie, 1875, 22 December, no. 848.

Le Moniteur de la Réunion 1868, 10 June, no. 47.

Le Néo-Calédonien 1884, Immigration blanche, 5 May, no. 441.

Le Néo-Calédonien 1884, 28 May, no. 451.

Nicole, R.-M. 1996, Noirs, Cafres et Créoles: etudes de la representation du non blanc réunionnais. L'Harmattan, Paris \& Montréal.

O’Reilly, P. 1953, Calédoniens: répertoire bio-bibliographique de la Nouvelle-Calédonie. Société des Océanistes, Paris.

Prudhomme, C. 1984, Histoire religieuse de la Réunion. Karthala, Paris.

Ricquebourg, L.J.C. 1976, Dictionnaire généalogique des familles de l'île Bourbon (1665-1767) pendant la régie de la Compagnie des Indes. Association des chercheurs de l’Océan Indien, Aix-enProvence.

Speedy, K. 2007a, Colons, Créoles et Coolies: L'immigration réunionnaise en Nouvelle-Calédonie (XIXe siècle) et le tayo de Saint-Louis. L'Harmattan, Paris. 2007b, 'Réunion Creole in New Caledonia: What influence on Tayo?,' Journal of Pidgin and Creole Languages, vol. 22, no. 2: 193-230.

2008, 'Out of the Frying Pan and into the Fire: Réunionese Immigrants and the Sugar Industry in Nineteenth-century New Caledonia,' New Zealand Journal of French Studies, vol. 29, no. 2, 5-19. 2009, 'Who were the Réunion Coolies of Nineteenth-Century New Caledonia?' Journal of Pacific History, vol. 44, no. 2, 123-140.

Terrier, C. 2000, 'La colonisation de peuplement libre en Nouvelle-Calédonie (1889-1909),' unpublished Ph.D. thesis, Université de la Nouvelle-Calédonie, Nouméa.

Terrier-Douyère, C. 1998, 'Tous metis,' in Le Mémorial Calédonien, (ed.) G. Blandinières, Planète Mémo, Nouméa, 377-379. 